\title{
KONDISI JALAN DENGAN PERSYARATAN TEKNIS KENDARAAN TERHADAP KEJADIAN KECELAKAAN
}

\author{
Teddi Fadilah $^{1)}$, Ida Farida ${ }^{2)}$ \\ ${ }^{1}$ Program Studi Teknik Sipil, Fakultas Teknik, Institut Teknologi Garut, Jawa Barat, \\ Indonesia \\ E-mail: teddifadilah@gmail.com \\ E-mail: idafarida@itg.ac.id
}

\begin{abstract}
Bandung Regency, Garut Regency and Tasikmalaya City are areas that are crossed by class III national roads. On this class III national road, there are several locations that often contribute to accidents. There are still vehicles that are not roadworthy and excessive transportation operating on the road, with these conditions the study seeks to find out how the implementation of vehicle feasibility testing with direct observation methods in the field, knowing the relationship of vehicles that do not pass the roadworthiness test with the incidence of accidents by usingcorrelation analysis. rank spearman uses SPSS and road conditions in accident-prone areas on class III national roads. This study uses secondary data, accident data obtained from the police agency and vehicle data that did not pass the roadworthiness test from the Department of Transportation as well as direct observations in the field. In carrying out vehicle testing in the study area, everything is carried out according to procedures with applicable regulations with competent technicians. The correlation value between variables has no significant (mean) relationship with a value greater than 0.05. The level of strength (closeness) of the relationship in Bandung Regency and Garut Regency is weak, while in Tasikmalaya City it is sufficient. From the three existing areas based on road conditions, the most vulnerable areas were found, namely on the incline/descendance of Gentong with a bend degree of $77^{\circ}$, an average slope of $0.123 \mathrm{~m} / \mathrm{m}$ with a 2-lane 1-lane road type (not divided).
\end{abstract}

Keywords: accident, road conditions, spearman rank, vehicle worthy test.

\begin{abstract}
ABSTRAK
Kabupaten Bandung, Kabupaten Garut dan Kota Tasikmalaya merupakan daerah terlewati jalan nasional kelas III. Pada jalan nasional kelas III ini ada beberapa lokasi yang kerap menyumbang terjadinya kecelakaan. Masih adanya kendaraan yang tidak laik jalan dan pengangkutan yang berlebihan beroperasi dijalan, dengan kondisi tersebut penelitian berupaya untuk mengetahui bagaimana pelaksanaan pengujian kelaikan kendaraan dengan metode observasi secara langsung di lapangan, mengetahui hubungan kendaraan yang tidak lolos uji laik dengan kejadian kecelakaan dengan menggunakan analisis korelasi rank spearman menggunakan SPSS dan kondisi jalan di daerah rawan kecelakaan pada jalan nasional kelas III. Studi ini menggunakan data sekunder, data kecelakaan diperoleh dari instansi kepolisisan dan data kendaraan yang tidak lolos uji laik jalan dari Dinas Perhubungan serta observasi secara langsung di lapangan. Dalam pelaksanaan pengujian kendaraan di daerah studi semua dilaksanakan sesuai prosedur dengan peraturan yang berlaku dengan teknisi yang berkompeten. Nilai korelasi antar variabel tidak ada hubungan yang signifikan (berarti) dengan nilai lebih besar dari 0,05. Tingkat kekuatan (keeratan) hubungan di Kabupaten Bandung dan Kabupaten Garut adalah lemah, sedangkan di Kota Tasikmalaya adalah cukup. Dari tiga wilayah yang ada berdasarkan kondisi jalan didapatkan daerah paling rawan yaitu di tanjakan/turunan Gentong dengan derajat tikungan $77^{\circ}$, kelandaian rata-rata $0,123 \mathrm{~m} / \mathrm{m}$ dengan jenis jalan 2 jalur 1 arah lajur (tidak terbagi).
\end{abstract}

Kata kunci: kecelakaan, kondisi jalan, rank spearman, uji laik kendaraan. 


\section{PENDAHULUAN}

Transportasi mengacu pada pemindahan barang dan atau orang dari satu tempat ke tempat lainnya (Warpani, 2002), sehingga perlu diarahkan dengan sistem transportasi yang andal, berkemampuan tinggi, terpadu, tertib, aman, lancar, nyaman, efisien, selamat, dan mendukung mobilitas dan pola distribusi manusia, barang, dan jasa (HARDAYA, U. K., \& Furi Sari Nurwulandari, 2017). Salah satu yang mempengaruhi sistem transportasi adalah kecelakaan lalulintas yang yang diakibatkan oleh faktor manusia, kendaraan, dan jalan (infrastruktur) (Kawangmani, M. E. P., Pratama, Y. P., \& Samudro, n.d.).

Selain faktor kendaraan, perlu juga diperhatikan keterjaminan kelayakan kendaraan penumpang atau barang yang diawasi oleh pemerintah (Farida, I., \& Santosa, 2018) berupa uji KIR (uji berkala) yang wajib dilakukan untuk mobil penumpang umum, bus, barang, kereta gandengan, dan kereta tempelan yang dioperasikan di jalan (Y., Lestari, L., 2019).

\section{TINJAUAN PUSTAKA}

\subsection{Keselamatan Jalan}

Keselamatan jalan berkaitan dengan kecelakaan lalu lintas. Kecelakaan lalu lintas adalah kecelakaan yang terjadi di jalan raya, yang melibatkan kendaraan dengan atau tanpa pengguna jalan lain, yang menimbulkan korban jiwa dan/atau kerugian harta benda (Pemerintah Republik Indonesia, 2009).

Keselamatan jalan meliputi budaya serta pendidikan berlalulintas pengguna jalan, aspek teknis kendaraan, aspek teknis konstruksi jalan serta kondisi perkerasan, desain ruas jalan, jarak pandang kendaraan, kelengkapan rambu atau petunjuk jalan, dan peraturan atau kebijakan peraturan setempat. Kecelakaan lalu lintas didolongkan pada 3 golongan, kecelakaan lalu lintas ringan, sedang, dan berat (Adlina dan Nurlaela, 2021), dengan 3 jenis korban kecelakaan meninggal dunia, luka berat, dan luka ringan (Farida, Santosa, dan Sutandi, 2019).

Secara umum ada empat faktor utama penyebab kecelakaan. Faktor penggerak/pengemudi (pengguna jalan), faktor kendaraan (kendaraan), faktor lingkungan jalan (lingkungan jalan raya). Biasanya kecelakaan tidak hanya disebabkan oleh satu faktor, tetapi juga akibat interaksi antar faktor lainnya. Faktor - faktor tersebut antara lain:

1. Faktor mengemudi: kondisi fisik (mabuk, lelah, sakit, dan lainnya.), kemampuan mengemudi, penyeberangan jalan atau pejalan kaki yang ceroboh, dan lain sebagainya.

2. Faktor kendaraan: kondisi mesin, rem, lampu, ban, beban, dan lain sebagainya.

3. Faktor lingkungan jalan: desain jalan (median, kemiringan, rute, jenis permukaan dan lain sebagainya), pengaturan lalu lintas (rambu, rambu, lampu lalu lintas), dan lain sebagainya.

4. Faktor cuaca: hujan, kabut, asap, angin dan lain sebagainya

\subsection{Pengujian Kendaraan Bermotor}

Pengujian kendaraan bermotor sering disebut juga kir kendaraan bermotor, kir berasal dari bahasa keur (Bahasa belanda) yang artinya berhitung. Pelaksanaan pengujian kendaraan bermotor bertujuan untuk: 1) memberikan fasilitas jaminan keselamatan secara teknis terhadap penggunaan kendaraan bermotor, 2) 
melestarikan lingkungan sekitar dari kemungkinan terjadinya pencemaran yang dihasilkan dari penggunaan kendaraan bermotor di jalan, dan 3) memberikan pelayanan secara terbuka kepada masyarakat.

Kebijakan pengujian kendaraan bermotor diatur dalam Undang-Undang Nomor: 22 Tahun 2009 Tentang Lalu Lintas dan Angkutan Jalan, Peraturan Pemerintah Nomor: 55 Tahun 2012 Tentang Kendaraan, dan Undang-Undang keputusan Menteri Perhubungan Tahun 1993 Nomor: KM.71 Tentang Pemeriksaan Rutin Kendaraan Bermotor. Jenis kendaraan harus menjalani pengujian adalah mobil penumpang umum/ bus, truk, kendaraan khusus, kereta gandingan, dan kereta tempelan.

Inspeksi kendaraan secara berkala berpengaruh terhadap kondisi kendaraan (Christensen dan Elvik, 2007). Setiap kendaraan bermotor yang beroperasi di jalan harus memenuhi persyaratan teknis dan laik jalan (UndangUndang Nomor: 22 Tahun 2009). Persyaratan teknis dan kelaikan jalan kendaraan bermotor, meliput: pemeriksaan fisik dan pengujian kendaraan, persyaratan teknis (pemeriksaan komposisi, peralatan, dimensi, bodi, desain teknis kendaraan, pemeriksaan kelaikan jalan,serta persyaratan, prosedur pengujian, masa berlaku dan bukti yang diberikan akan dibatasi lebih lanjut oleh peraturan pemerintah.

\subsection{Analisis Korelasi Rank Spearman}

Analisis korelasi rank spearman dapat digunakan untuk menguji hubungan antar variabel penelitian pada statistik nonparametrik (skala ordinal), nilai koefisien yang digunakan dalam analisis dan kriteria keeratan hubungan kedua variabel adalah sama dengan apa yang digunakan dalam korelasi person, tetapi yang digunakan adalah data yang tersedia dan selanjutnya dilakukan uji korelasi.

Dalam analisis ini memiliki tujuan untuk mengetahui: tingkat kekuatan (keeratan) hubungan dua variabel, arah / jenis hubungan dua variabel, apakah hubungan tersebut signifikan atau tidak. Kriteria tingkat kekuatan korelasi antara variabel berpedoman kepada nilai koefisien korelasi yang merupakan hasil dari analisis SPSS, dengan ketentuan nilai:

a. koefisien korelasi sebesar 0,00 - 0,25 = hubungan sangat lemah

b. koefisien korelasi sebesar $0,26-0,50=$ hubungan cukup

c koefisien korelasi sebesar 0,51 - 0,75 = hubungan kuat

d. koefisien korelasi sebesar 0,76 - 0,99= hubungan sangat kuat

e. koefisien korelasi sebesar 1,00 = hubungan sempurna

Kriteria signifikan korelasikKekuatan dan arah korelasi antara dua variabel mempunyai arti jika hubungan antar variabel tersebut bernilai signifikan. Dapat dikatakan ada hubungan signifikan, jika nilai sig. (2-tailed) hasil perhitungan lebih kecil dari nilai 0,05 atau 0,01. Sementara itu, jika nilai sig. (2-tailed) lebih besar dari 0,05 atau 0,01, maka hubungan antar variabel tersebut dapat dikatakan tidak signifikan atau tidak berarti (Jaya dan Ardat, 2013; Gani dan Amalia, 2015).

\section{BAHAN DAN METODE}

\section{a. Tahapan Penelitian}

Dalam proses penyusunan skripsi dilakukan beberapa tahapan penting. Lebih jelasnya dapat dilihat pada gambar berikut. 


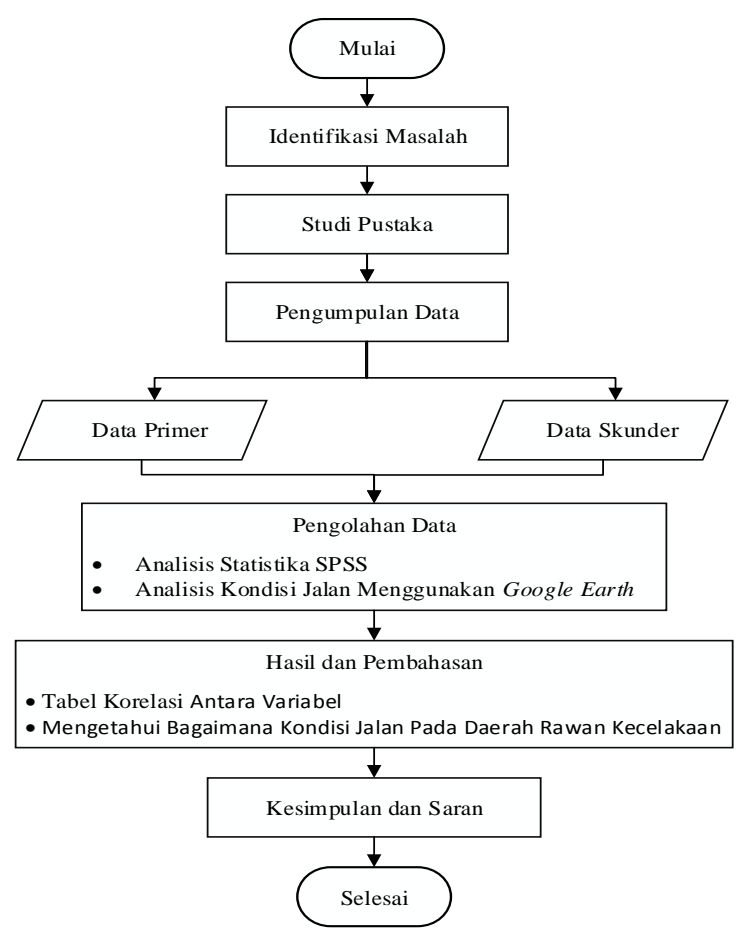

Gambar 3.1. Diagram Alur Penelitian

\section{b. Lokasi dan Waktu Penelitian}

Lokasi yang dijadikan sebagai bahan penelitian adalah pelaksanaan pengujian kendaraan dan daerah rawan jalan nasional kelas III Kabupaten Bandung, Kabupaten Garut dan Kota Tasikmalaya. Penelitian ini berlangsung pada tahun 2021.

\section{c. Tahapan Analisis}

Dalam analisis data ini dimaksudkan untuk mengetahui kesesuaian kelas jalan pada titik rawan kecelakaan, hubungan kelaikan kendaraan terhadap kejadian kecelakaan, dan pelaksanaan pengujian berkala kendaraan. Adapun tahapan analisis sebagai berikut:

1. Kondisi jalan yang meliputi ruang milik jalan, ruang manfaat jalan dan ruang pengawasan jalan dengan metode observasi secara langsung di lapangan serta diukur ulanng dengan Google Earth (A., Purnomo, E. P., \& Kasiwi, 2020)[11].

2. Hubungan/korelasi kendaraan yang tidak lolos uji dengan kejadian kecelakaan yaitu dengan menggunakan metode uji korelasi rank spearman mengunakan program aplikasi SPSS.

3. Pelaksanaan pengujian berkala kendaraan bermotor yang dilaksanakan di masing-masing daerah yang dijadian sebagai tempat studi dengan metode observasi secara langsung di lapangan.

\section{d. Alat dan Bahan}

a. Alat Tulis Kantor (ATK) untuk mencatat data survei yang dibutuhkan.

b. Kamera/hp untuk mengambil dokumentasi yang dibutuhkan.

c. Meteran untuk mengukur lebar jalan dan yang lainnya. 
e. Teknik Pengumpulan Data

Teknik pengumpulan data dalam penelitian ini menggunakan teknik analisis deskriptif, dokumentasi, observasi, dan wawancara.

\section{HASIL DAN PEMBAHASAN}

\section{Pelaksanaan Pemeriksaan Kendaraan}

Pelaksanaan pengujian mekanis (laik jalan) di dalam gedung uji menggunakan alat uji standar, meliputi:

1. Uji Ketembusan Sinar (Alat Tint Tester)

2. Uji Kebisingan Suara Klakson (Alat Sound Level Meter)

3. Uji Emisi Gas Buang Alat Gas Analyzer/ Co Hc Tester (Bensin)

Alat Smoke Tester/ Uji Kepekatan Asap (Solar/ Diesel)

4. Uji Under Cariage/ Uji Baguan Bawah Kendaraan

5. Uji Daya Pancar Arah Sinar Lampu Utama (Alat Uji Head Light Tester)

6. Uji Kincup Roda Depan (Alat Uji Side Slip Tester

7. Uji Timbang Berat Sumbu Kendaraan (Axle Load Meter)

8. Uji Effisiensi Daya Pengereman (Alat Brake Tester)

9. sumbu kendaraan bermotor

10. Uji Kesesuaian Alat Penunjuk Kecepatan (Spedometer Tester)

Alat-alat pengujian dalam keadaan baik dan petugas penguji berkompeten yang dibekali pendidikan dan latihan khusus. Dalam pelaksanaan pengujian dilaksanakan dengan baik dan sesuai dengan prosedur sebagaimana yang telah ditetapkan oleh pemerintah dalam Undang Undang Nomor: 22 Tahun 2009 tentang Lalu lintas dan Angkutan Jalan (Sitorus, 2013).

\section{Analisis Korelasi Rank Spearman}

Dalam penelitian korelasi rank spearman diperlukan data kendaraan yang mengalami kecelakaan serta kendaraan yang tidak lolos uji laik dalam hal ini peneliti mengambil studi bus dan truk, lebih jelasnya tercantum pada Tabel 1.

Table 4.1. Data di Kabupaten Bandung Tahun 2020

\begin{tabular}{cccc}
\hline No & $\begin{array}{c}\text { Jenis } \\
\text { Kendaraan }\end{array}$ & $\begin{array}{c}\text { Jumlah } \\
\text { Kecelakaan }\end{array}$ & $\begin{array}{c}\text { Jumlah Tidak } \\
\text { Lolos Uji }\end{array}$ \\
\hline 1 & Bus & 9 & 43 \\
\hline 2 & Truk & 51 & 363 \\
\hline
\end{tabular}

Hasil analisis korelasi data menggunakan program SPSS 20 dengan menggunakan metode rank spearman di Kabupaten Bandung, dapat dilihat pada Tabel 2.

Table 4.2. Hasil Analisis Rank Spearman Bus dan Truk Kabupaten Bandung

\begin{tabular}{|c|c|c|c|c|}
\hline \multicolumn{5}{|c|}{ Correlations } \\
\hline & & & Tidak Lolos Uji & Kecelakaan \\
\hline \multirow[t]{7}{*}{ Spearman's rho } & Tidak Lolos & Correlation & 1,000 & ,222 \\
\hline & Uji & Coefficient & & \\
\hline & & Sig. (2-tailed) & & ,488 \\
\hline & & $\mathrm{N}$ & 12 & 12 \\
\hline & Kecelakaan & Correlation & ,222 & 1,000 \\
\hline & & Sig. (2-tailed) & ,488 & \\
\hline & & $\mathrm{N}$ & 12 & 12 \\
\hline
\end{tabular}




\section{Melihat signifikansi hubungan}

Berdasarkan output Tabel 2 diketahui nilai signifikansi sebesar 0,488 > lebih besar dari 0,05 maka disimpulkan antara variabel kendaraan yang tidak lolos uji dengan kejadian kecelakaan tidak ada hubungan yang signifikan [18] (Rahmat, K. N., \& Ahri, 2021).

2. Melihat tingkat kekuatan (keeratan) hubungan

Angka koefisien korelasi sebesar 0,222 artinya tingkat hubungan kekuatan (korelasi) antara variabel kendaraan yang tidak lolos uji dengan kejadian kecelakaan berarti lemah [19] (Rita Mayawati, 2017).

3. Melihat arah (jenis) Hubungan

Angka koefisien bernilai positif, 0,222, sehingga hubungan kedua variabel tersebut memiliki jenis hubungan searah, dengan demikian dapat dikatakan semakin meningkat kendaraan yang tidak lolos uji maka kecelakaan juga akan meningkat [20] (Katarina, 2019).

3.

Data kecelakaan dan kendaraan tidak lolos uji Kabupaten Garut dapat dilihat pada Tabel

Table 4.3. Data di Kabupaten Garut

\begin{tabular}{cccc}
\multicolumn{4}{c}{ Tahun 2020 } \\
\hline \multirow{2}{*}{ No } & $\begin{array}{c}\text { Jenis } \\
\text { Kendaraan }\end{array}$ & $\begin{array}{c}\text { Jumlah } \\
\text { Kecelakaan }\end{array}$ & $\begin{array}{c}\text { Jumlah Tidak Lolos } \\
\text { Uji }\end{array}$ \\
\hline 1 & Bus & 17 & 24 \\
\hline 2 & Truk & 38 & 130 \\
\hline
\end{tabular}

Hasil analisis korelasi rank spearman Kabupaten Garut dapat dilihat pada Tabel 4.

Table 4.4. Hasil Analisis Rank Spearman Bus dan Truk Kabupaten Garut

\begin{tabular}{|cll|r|r|}
\hline \multicolumn{4}{|c|}{ Correlations } \\
\hline \multirow{2}{*}{$\begin{array}{c}\text { Spearman's } \\
\text { rho }\end{array}$} & Tidak Lolos & Correlation & Tidak Lolos Uji & $\begin{array}{c}\text { Kecelakaa } \\
\mathrm{n}\end{array}$ \\
& Uji & Coefficient & 1,000 &,- 198 \\
& Sig. (2-tailed) & &, 538 \\
& $\mathrm{~N}$ & 12 & 12 \\
\cline { 2 - 5 } & Kecelakaan & Correlation &,- 198 & 1,000 \\
& & Coefficient & & \\
& & Sig. (2-tailed) &, 538 & 12 \\
\hline & $\mathrm{N}$ & 12 & \\
\hline
\end{tabular}

\section{Melihat signifikansi hubungan}

Berdasarkan output Tabel 2 diketahui nilai signifikansi sebesar 0,538 > lebih besar dari 0,05 maka disimpulkan antara variabel kendaraan yang tidak lolos uji dengan kejadian kecelakaan tidak ada hubungan yang signifikan.

\section{Melihat tingkat kekuatan (keeratan) hubungan}

Angka koefisien korelasi sebesar -0,198 artinya tingkat hubungan kekuatan (korelasi) antara variabel kendaraan yang tidak lolos uji dengan kejadian kecelakaan berarti lemah.

3. Melihat arah (jenis) Hubungan

Angka koefisien bernilai negatif yaitu $-0,198$ sehingga hubungan kedua variabel tersebut bersifat memiliki jenis hubungan tidak searah, dengan demikian dapat disimpulkan bahwa pengaruh dari jumlah kendaraan yang tidak lolos uji tidak mempengaruhi jumlah kecelakaan. 
Data kecelakaan dan kendaraan tidak lolos uji di Kota Tasikmalayadapat dilihat pada Tabel 5 .

Table 4.5. Data di Kota Tasikmalaya Tahun 2020

\begin{tabular}{cccc}
\hline No & $\begin{array}{c}\text { Jenis } \\
\text { Kendaraan }\end{array}$ & $\begin{array}{c}\text { Jumlah } \\
\text { Kecelakaan }\end{array}$ & $\begin{array}{c}\text { Jumlah Tidak Lolos } \\
\text { Uji }\end{array}$ \\
\hline 1 & Bus & 17 & 24 \\
\hline 2 & Truk & 38 & 130 \\
\hline
\end{tabular}

Hasil analisis korelasi rank spearman Kota Tasikmalaya dapat dilihat pada Tabel 6.

Table 4.6. Hasil Analisis Rank Spearman Bus dan Truk Kota Tasikmalaya Correlations

\begin{tabular}{|cll|r|r|}
\hline & & \multicolumn{2}{c|}{$\begin{array}{c}\text { Tidak Lolos } \\
\text { Uji }\end{array}$} & Kecelakaan \\
\hline $\begin{array}{c}\text { Spearman's } \\
\text { rho }\end{array}$ & Tidak Lolos & $\begin{array}{l}\text { Correlation } \\
\text { Uji }\end{array}$ & 1,000 &, 442 \\
& & $\begin{array}{l}\text { Coefficient } \\
\text { Sig. (2- } \\
\text { tailed) }\end{array}$ & &, 151 \\
& & $\mathrm{~N}$ & 12 & 12 \\
\cline { 2 - 5 } & Kecelakaan & $\begin{array}{l}\text { Correlation } \\
\text { Coefficient } \\
\text { Sig. (2- } \\
\text { tailed) } \\
\text { N }\end{array}$ &, 442 & 1,000 \\
& &, 151 & \\
& & 12 & 12 \\
\hline
\end{tabular}

\section{Melihat signifikansi hubungan}

Berdaasarkan data output pada Tabel 6, diketahui nilai signifikansi sebesar 0,151 > lebih besar dari 0,05 maka antara variabel kendaraan yang tidak lolos uji dengan kejadian kecelakaan tidak ada hubungan yang signifikan (berarti).

\section{Melihat tingkat kekuatan (keeratan) hubungan}

Angka koefisien korelasi sebesar 0,442 artinya tingkat hubungan kekuatan (korelasi) antara variabel kendaraan yang tidak lolos uji dengan kejadian kecelakaan berarti cukup.

3. Melihat arah (jenis) Hubungan

Angka koefisien bernilai positif yaitu 0,442 sehingga hubungan kedua variabel tersebut memiliki jenis hubungan searah, dengan demikian dapat disimpulkan bahwa semakin meningkat kendaraan yang tidak lolos uji maka kecelakaan juga akan meningkat.

\section{Daerah Rawan Kecelakaan}

Daerah rawan pada jalan nasional kelas III Kabupaten Bandung berlokasi di daerah turunan Nagreg, di Kabupaten Garut berlokasi di daerah tanjakan Andir Kec. Malangbong dan di Kabupaten Tasikmalaya berlokasi di daerah tanjakan Gentong Kec. Kadipaten.

\section{Kondisi Jalan Pada Daerah Rawan di Kabupaten Bandung}

Lebar badan jalan rawan di daerah Turunan Nagreg yaitu 11 meter dapat dilihat pada Gambar 2. 


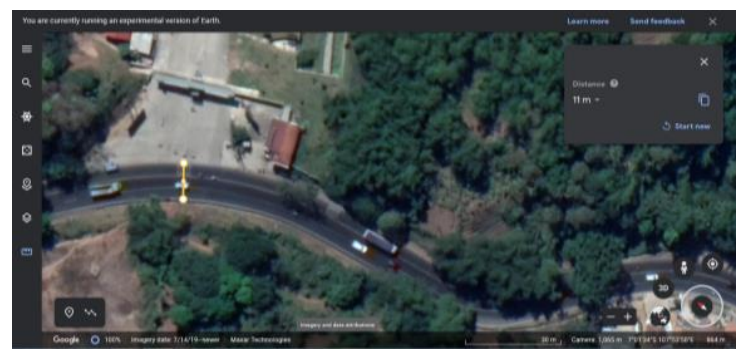

Gambar 4.1. Lebar Badan Jalan Daerah Rawan Kab. Bandung

Untuk mencari derajat tikungan dilakukan dengan menggunakan bantuan Google Earth dan Autocad, didapatkan derajat tikungan $37^{\circ}$ dan $31^{\circ}$. Untuk lebih jelasnya dapat dilihat pada Gambar 3.

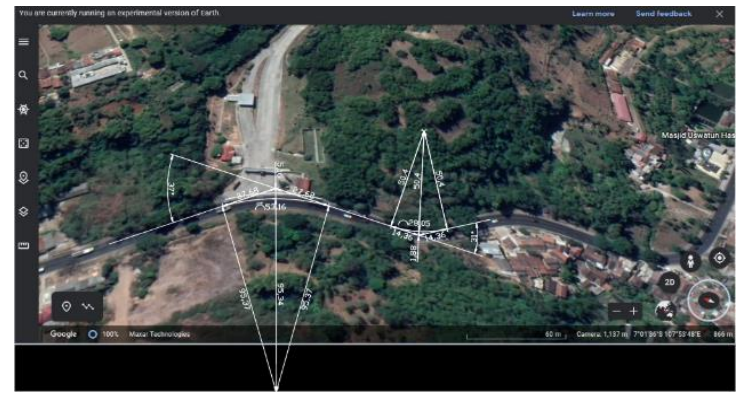

Gambar 4.2. Derajat Tikungan Daerah Rawan Kabupaten Bandung

Nilai beda elevasi pada jarak 87 meter sebesar 7 mdpl dengan kelandaian rata-rata sebesar $0,08 \mathrm{~m} / \mathrm{m}$. Nilai beda elevasi pada jarak 43,85 meter adalah 6 mdpl dengan kelandaian rata-rata sebesar $0,136 \mathrm{~m} / \mathrm{m}$. Nilai beda elevasi pada jarak 49,2 meter adalah 10 mdpl dengan kelandaian rata-rata sebesar 0,203 m/m. Gambaran elevasi dapat dilihat pada Gambar 4.

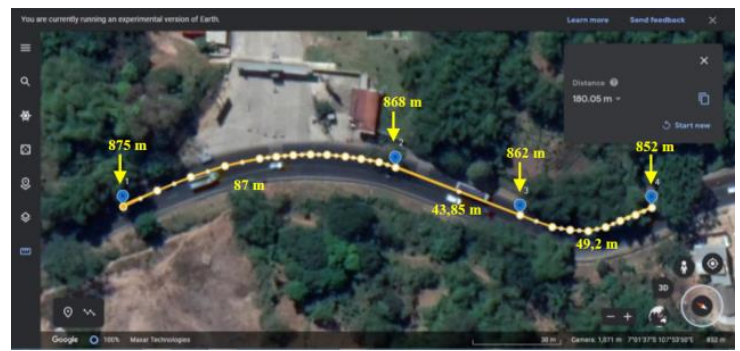

Gambar 2.3 Elevasi dan Jarak di Daerah Rawan Kecelakaan Kabupaten Bandung

\section{Kondis Jalan Pada Daerah Rawan di Kabupaten Garut}

Lebar badan jalan di tanjakan Andir Kec. Malangbong yaitu 7,5 meter dapat dilihat pada Gambar 5.

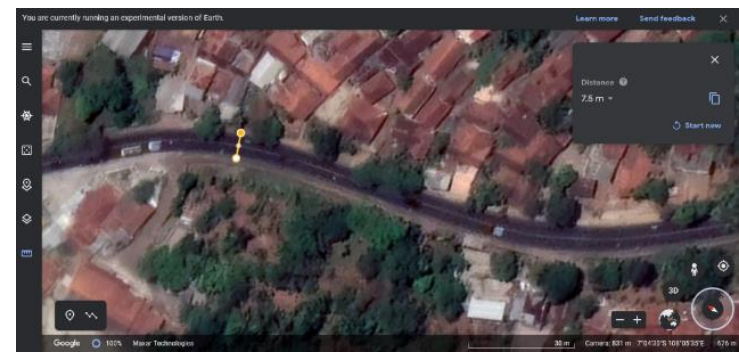


Gambar4.4 Lebar Badan Jalan Daerah Rawan Kabupaten Garut Gambar 6.

Derajat tikungan $36^{\circ}$ dan $32^{\circ}$. Untuk lebih jelasnya dapat dilihat pada

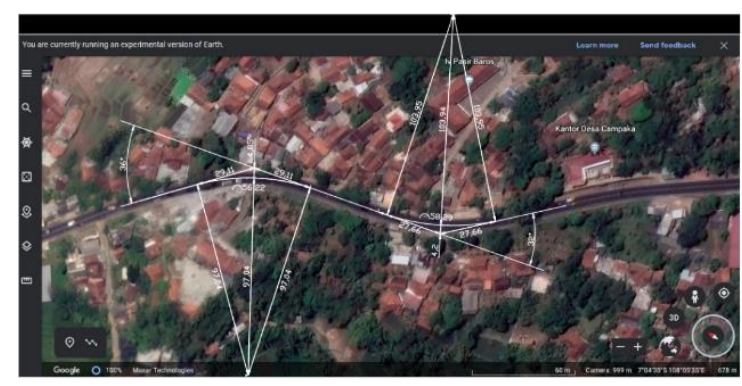

Gambar 4.5 Derajat Tikungan Daerah Rawan Kabupaten Garut

Nilai beda elevasi pada jarak 68 meter adalah 6 mdpl dengan kelandaian rata-rata sebesar $0,088 \mathrm{~m} / \mathrm{m}$. Nilai beda elevasi jarak 38 meter adalah $4 \mathrm{mdpl}$ dengan kelandaian rata-rata sebesar $0,083 \mathrm{~m} / \mathrm{m}$. Nilai beda elevasi jarak 82,7 meter adalah $12 \mathrm{mdpl}$ dengan kelandaian rata-rata sebesar $0,145 \mathrm{~m} / \mathrm{m}$. Detail elevasi dapat dilihat pada Gambar 7.

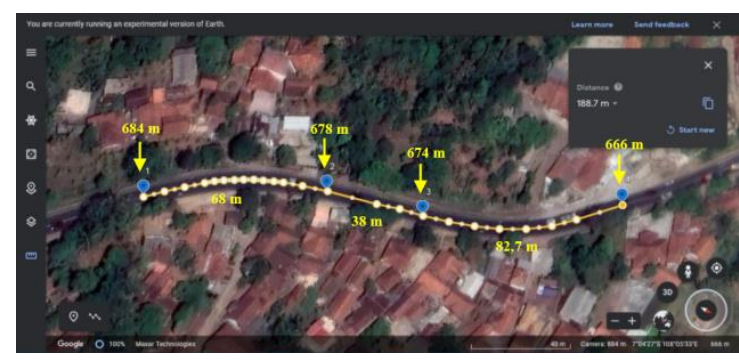

Gambar 4.6 Elevasi dan Jarak di Daerah Rawan Kecelakaan Kab. Garut

Kondis Jalan Pada Daerah Rawan di Kabupaten Tasikmalaya

Lebar badan jalan di tanjakan Gentong Kec. Kadipaten yaitu 9,2 meter dapat dilihat pada Gambar 8.

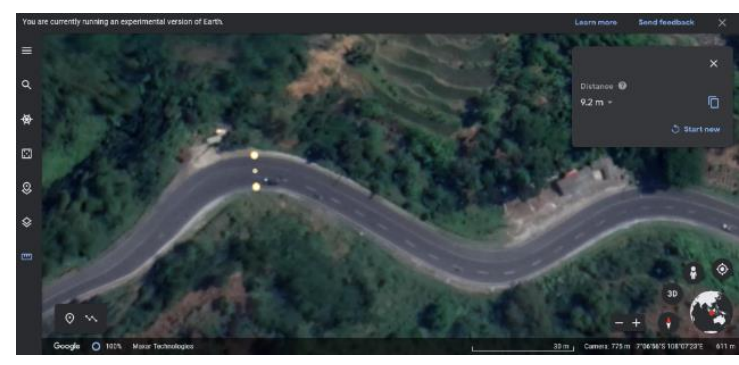

Gambar 4.7 Lebar Badan Jalan Daerah Rawan Kabupaten Tasikmalaya Gambar 9.

Derajat tikungan $77^{\circ}$ dan $62^{\circ}$. Untuk lebih jelasnya dapat dilihat pada 


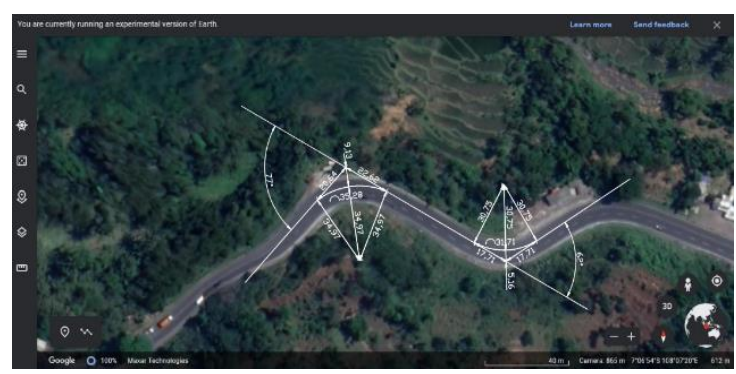

Gambar4.8 Derajat Tikungan Daerah Rawan Kabupaten Tasikmalaya

Nilai elevasi pada jarak 40,6 meter adalah 5 mdpl dengan kelandaian ratarata sebesar $0,123 \mathrm{~m} / \mathrm{m}$. Nilai elevasi jarak 39,2 meter adalah 4 mdpl dengan kelandaian rata-rata sebesar $0,102 \mathrm{~m} / \mathrm{m}$. Nilai elevasi pada jarak 43 meter adalah 4 mdpl dengan kelandaian rata-rata sebesar $0,093 \mathrm{~m} / \mathrm{m}$. Detail elevasi dapat dilihat pada Gambar 10.

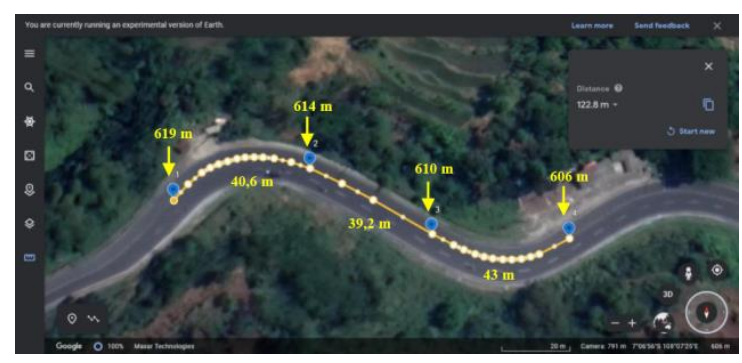

Gambar 4.9 Elevasi dan Jarak di Daerah Rawan Kecelakaan Kab. Tasikmalaya

Table 4.7. Kondisi Jalan Pada Daerah Rawan Kecelakaan

\begin{tabular}{|c|c|c|c|c|}
\hline \multirow[b]{2}{*}{ No } & \multirow[b]{2}{*}{ Tinjauan } & \multicolumn{3}{|c|}{ Kondisi } \\
\hline & & $\begin{array}{l}\text { Kabupaten } \\
\text { Bandung }\end{array}$ & Kabupaten garut & $\begin{array}{c}\text { Kabupaten } \\
\text { Tasikmalaya }\end{array}$ \\
\hline 1. & $\begin{array}{l}\text { Lokasi daerah } \\
\text { rawan } \\
\text { kecelakaan }\end{array}$ & $\begin{array}{l}\text { Turunan Nagreg } \\
\text { Kec. Nagreg Kab. } \\
\text { Bandung }\end{array}$ & $\begin{array}{l}\text { Tanjakan/Turunan } \\
\text { Andir Kec. } \\
\text { Malangbong Kab. } \\
\text { Garut }\end{array}$ & $\begin{array}{l}\text { Tanjakan/Turunan } \\
\text { Gentong Kec. } \\
\text { Kadipaten Kab. } \\
\text { Tasikmalaya }\end{array}$ \\
\hline & $\begin{array}{l}\text { Lebar lajur lalu } \\
\text { lintas }\end{array}$ & 11 meter & 7,5 meter & 9,2 meter \\
\hline 3. & $\begin{array}{l}\text { Jumlah arah dan } \\
\text { jumlah lajur }\end{array}$ & $\begin{array}{l}\text { Jalan } 1 \text { jalur } 1 \text { arah } \\
\text { lajur (tidak terbagi) }\end{array}$ & $\begin{array}{l}\text { Jalan } 2 \text { jalur } 1 \text { arah } \\
\text { lajur (tidak terbagi) } \\
\text { masing-masing jalur } \\
\text { dengan lebar yang } \\
\text { sama yaitu } 3,75 \text { meter }\end{array}$ & $\begin{array}{l}2 \text { jalur } 1 \text { arah lajur } \\
\text { (tidak terbagi) dari } \\
\text { Garut menuju } \\
\text { Tasikmalaya 5,75 m, } \\
\text { dari arah Tasikmalaya } \\
\text { menuju Garut 3,45 m. }\end{array}$ \\
\hline 4. & Lebar bahu jalan & 1,8 meter & 1,6 meter & 2 meter \\
\hline & Lebar median & $\begin{array}{l}\text { Tidak memiliki } \\
\text { median }\end{array}$ & $\begin{array}{l}\text { Tidak memiliki } \\
\text { median }\end{array}$ & $\begin{array}{l}\text { Tidak memiliki } \\
\text { median }\end{array}$ \\
\hline 6. & Derajat tikungan & $\begin{array}{l}\text { Tikungan pertama } \\
37^{\circ} \text { dan pada } \\
\text { tikungan kedua } 31^{\circ}\end{array}$ & $\begin{array}{l}\text { Tikungan pertama } 36^{\circ} \\
\text { dan pada tikungan } \\
\text { kedua } 32^{\circ}\end{array}$ & $\begin{array}{l}\text { Tikungan pertama } 77^{\circ} \\
\text { dan pada tikungan } \\
\text { kedua } 62^{\circ}\end{array}$ \\
\hline
\end{tabular}




\begin{tabular}{|c|c|c|c|c|}
\hline \multirow[b]{2}{*}{ No } & \multirow[b]{2}{*}{ Tinjauan } & \multicolumn{3}{|c|}{ Kondisi } \\
\hline & & $\begin{array}{c}\text { Kabupaten } \\
\text { Bandung }\end{array}$ & Kabupaten garut & $\begin{array}{l}\text { Kabupaten } \\
\text { Tasikmalaya }\end{array}$ \\
\hline 7. & $\begin{array}{l}\text { Kelandaian jalan } \\
\text { di tanjakan atau } \\
\text { turunan }\end{array}$ & $\begin{array}{l}\text { Tikungan pertama } \\
7 \mathrm{~m} \text {, panjang } 87 \mathrm{~m} \text {, } \\
\text { rata-rata kemiringan } \\
0,08 \mathrm{~m} / \mathrm{m} \text {. } \\
\text { Tikungan Kedua } 10 \\
\mathrm{~m} \text {, panjang } 49,2 \\
\text { rata-rata kemiringan } \\
0,2 \mathrm{~m} / \mathrm{m} .\end{array}$ & $\begin{array}{l}\text { Tikungan pertama } 6 \mathrm{~m} \text {, } \\
\text { panjang } 68 \mathrm{~m} \text {, rata-rata } \\
\text { kemiringan } 0,088 \mathrm{~m} / \mathrm{m} \text {. } \\
\text { Tikungan Kedua } 12 \\
\mathrm{~m} \text {, panjang } 82,7 \mathrm{~m} \text {, } \\
\text { rata-rata kemiringan } \\
0,145 \mathrm{~m} / \mathrm{m}\end{array}$ & $\begin{array}{l}\text { Tikungan pertama } 5 \mathrm{~m} \text {, } \\
\text { panjang } 40,6 \mathrm{~m} \text {, rata- } \\
\text { rata kemiringan } 0,123 \\
\mathrm{~m} / \mathrm{m} . \\
\text { Tikungan Kedua } 4 \mathrm{~m} \text {, } \\
\text { panjang } 43 \mathrm{~m} \text {, rata- } \\
\text { rata kemiringan } 0,09 \\
\mathrm{~m} / \mathrm{m}\end{array}$ \\
\hline 8. & $\begin{array}{l}\text { Pagar } \\
\text { keselamatan }\end{array}$ & $\begin{array}{l}\text { Tidak ada pagar } \\
\text { keselamatan pada } \\
\text { daerah rawan }\end{array}$ & $\begin{array}{l}\text { Tidak ada pagar } \\
\text { keselamatan pada } \\
\text { daerah rawan }\end{array}$ & $\begin{array}{l}\text { jenis pagar pembatas } \\
\text { besi galvanis } \\
\text { (guardrail) }\end{array}$ \\
\hline 9. & $\begin{array}{l}\text { Macam } \\
\text { kendaraan yang } \\
\text { melintas }\end{array}$ & $\begin{array}{l}\text { Semua jenis } \\
\text { kendaraan }\end{array}$ & $\begin{array}{l}\text { Semua jenis } \\
\text { kendaraan }\end{array}$ & $\begin{array}{l}\text { Semua jenis } \\
\text { kendaraan }\end{array}$ \\
\hline
\end{tabular}

Daerah rawan kecelakaan biasanya kerap dihubungkan dengan bagaimana kondisi tikungan, kelaindaian serta jarak pandang. Berdasarkan Tabel 7 bahwa dari tiga daerah rawan kecelakaan tersebut, daerah yang paling memicu terjadinya kecelakaan yaitu di jalan tanjakan/turunan Gentong Kec. Kadipaten Kabupaten Tasikmalaya dengan derajat tikungan $77^{\circ}$, kelandaian rata-rata $0,123 \mathrm{~m} / \mathrm{m}$, lebar jalan 9,2 meter, semua jenis kendaraan melewati jalan ini mulai dari kendaraan roda dua, roda tiga, roda empat dan sebagainya dan jenis jalur serta lajur yaitu 2 jalur 1 arah lajur (tidak terbagi)

\section{KESIMPULAN}

Kecelakaan yang terjadi di Kabupaten Bandung, Kabupaten Garut, dan Kota Tasikmalaya dengan data Tahun 2020 dapat disimpulkan:

1. Variabel kendaraan bus dan truk tidak ada hubungan yang signifikan (berarti) antara variabel.

2. Tingkat kekuatan (keeratan) hubungan dengan kondisi lemah terdapat di Kabupaten Bandung sebesar 0,222 dan Kabupaten Garut sebesar 0,198, sedangkan di Kota Tasikmalaya hubungan keeratannya cukup dengan nilai 0,442 .

3. Arah (jenis) hubungan Kabupaten Bandung dan Kota Tasikmalaya bersifat serah, maka dapat disimpulkan semakin meningkat kendaraan yang tidak lolos uji kecelakaan juga akan meningkat sedangkan Kabupaten Garut bersifat tidak serah, maka dapat disimpulkan bahwa pengaruh dari jumlah kendaraan yang tidak lolos uji tidak mempengaruhi jumlah kecelakaan.

4. Daerah rawan di jalan nasional Kelas III berada di daerah tanjakan/turunan Gentong, dengan derajat tikungan $77^{\circ}$, kelandaian rata-rata $0,123 \mathrm{~m} / \mathrm{m}$ dan jenis jalan 2 jalur 1 arah lajur (tidak terbagi). 


\section{DAFTAR PUSTAKA}

A., Purnomo, E. P., \& Kasiwi, A. N. (2020). Kesiapan kota yogyakarta dalam pembangunan transportasi yang berkelanjutan. Ilmiah Ilmu Administrasi Negara, $7(1), 148-158$.

Adlina, Y.Y.N., dan Nurlaela, S. (2021), "Analisis Faktor Kecelakaan Lalu Lintas Surabaya Berdasarkan Perspektif Tata Ruang Melalui Pemodelan Spasial”, Jurnal Teknik ITS, 10(1), E13-E20.

Christensen, P., dan Elvik, R. (2007), "Effects on Accidents of Periodic Motor Vehicle Inspection in Norway", Accident Analysis and Prevention 39: 47-52, Institute of Transport Economic, Norway.

Farida, I., \& Santosa, W. (2018). Keselamatan angkutan bus di Kabupaten Garut. Jurnal Transportasi. Transportasi, 18(3), 211-218.

Farida, I., Santosa, W., dan Sutandi, A.C., (2019), "Karakteristik dan Biaya Kecelakaan Lalu Lintas di Kabupaten Garut", Jurnal Transportasi, 19(2), 143-150.

Gani, I., dan Amalia, S. (2015). Alat Analisis Data: Aplikasi Statistik untuk Penelituan Bidang Ekonomi dan Sosial. Penerbit Andi.

HARDAYA, U. K., \& Furi Sari Nurwulandari, D. P. (2017). Kajian Kinerja Operasional Angkutan Kota Di Kota Tanjungpinang (Studi Kasus: Angkutan Kota Trayek B). (Doctoral Dissertation, Fakultas Teknik).

Jaya, I., \& Ardat, A. (2013). Penerapan statistik untuk pendidikan

Katarina, E. (2019). PENGARUH KUALITAS PELAYANAN TERHADAP KEPUASAN PELANGGAN PADA RUMAH MAKAN AYAM KUDUS BANJARMASIN. Doctoral Dissertation, STIE Indonesia Banjarmasin.

Kawangmani, M. E. P., Pratama, Y. P., \& Samudro, B. R. (n.d.). Deskripsi Uji Berkala Kendaraan Bermotor Mobil Bus Antar Kota, Dampak Ekonomi dan Potensi Kecelakaan Lalu Lintas dalam Dimensi Pelaku USAha Otobus (Studi Kasus Trayek Irisan Solo-Semarang). Ilmu Ekonomi Dan Pembangunan, 17(1).

Rahmat, K. N., \& Ahri, R. A. (2021). Hubungan Penerapan Aspek Keselamatan dan Kesehatan Kerja dengan Pekerja Pengelasan di Bagian Produksi. Window of Public Health, 757-765.

Rita Mayawati, L. (2017). PENGARUH PERSON-ORGANIZATION FIT (PO-FIT) DAN KEPUASAN KERJA TERHADAP ORGANIZATIONAL CITIZENSHIP BEHAVIOUR (OCB). Fakultas Psikologi Universitas Katolik Soegijapranata.

Sitorus, B. (2013). Pengawasan Kegiatan Pengujian Kendaraan Bermotor Untuk Meningkatkan Keselamatan Dan Kelaiakan Jalan. Warta Penelitian Perhubungan, 25(1), 36-45.

Warpani, P. S. (2002). Pengelolaan Lalu Lintas dan Angkutan Jalan. ITB.

Y., Lestari, L., \& N. (2019). ANALISIS FUNGSI PENGAWASAN UJI BERKALA OLEH DINAS PERHUBUNGAN KOTA BATAM TERHADAP ANGKUTAN KOTA. DIMENSI, 8(3)(UJI BERKALA), 432-448. 